\title{
Dust exposure and mortality in an American chrysotile asbestos friction products plant
}

\author{
A D MCDONALD, ${ }^{1}$ J S FRY,' A J WOOLLEY, ${ }^{2}$ AND J C MCDONALD ${ }^{2}$ \\ From the Department of Epidemiology, ${ }^{1}$ St Mary's Hospital Medical School, and the TUC Centenary Institute \\ of Occupational Health, ${ }^{2}$ London School of Hygiene and Tropical Medicine, London, UK
}

\begin{abstract}
Cohort studies in three American asbestos factories were undertaken to investigate the effect of fibre type and manufacturing process on lung cancer, mesothelioma, and asbestosis. Reports have been published on a chrysotile textile plant in South Carolina and a mainly textile plant in Pennsylvania, which also used amphiboles. In the third plant in Connecticut friction products and packings were made from chrysotile only. In a cohort of 3641 men employed for one month or more, 1938-58, $3513(96.5 \%)$ were traced, $1267(36 \%)$ had died, and death certificates were obtained for $1228(96.9 \%)$. Individual exposures were estimated (in mcpf. years) from impinger measurements. Life table analyses using Connecticut mortality rates gave an SMR for all causes of 108.5 (USA 107.9). The SMR (all causes) for men who had worked for less than a year was 129.9 and for those who had worked for a year or more, 101.2. The equivalent SMRs for respiratory cancer were 167.4 and 136.7 respectively. Excluding men who had worked for less than a year, there was possible evidence of some increase in risk of lung cancer with increasing exposure, supported also by a "log-rank" (case-control) analysis, of the same order as that observed in chrysotile mining and milling. These findings may be compared with chrysotile textile manufacture where the risk of lung cancer was some 50 -fold greater. It is suggested that the differences in risk are perhaps related to the higher proportion of submicroscopic fibres in textile manufacture that may result from the traumatic carding, spinning, and weaving processes. No case of mesothelioma was found, consistent with a much lower risk of this tumour with chrysotile than with amphiboles. Twelve deaths (nine in men with very short and low asbestos exposure) were given ICD code 523 (pneumoconiosis); all but two were ascribed to anthracosilicosis or silicosis and none to asbestosis.
\end{abstract}

This paper presents the findings from the last of a series of parallel cohort mortality studies in three American asbestos product manufacturing plants. Reports have been published on the first, a chrysotile textile plant in South Carolina ${ }^{1}$ and the second, a mainly textile plant in Pennsylvania which used some amosite and a little crocidolite as well as chrysotile. ${ }^{2}$ In this third plant, in Connecticut, friction materials and packings were prociuced from chrysotile only until 1957, when a little anthophyllite was also used.

The objectives of the triple study were (1) to compare the health effects in terms of malignant disease and pulmonary fibrosis of manufacturing chrysotile asbestos with those entailed in its mining and milling which had previously been studied ${ }^{3}$ and Received 13 June 1983 Accepted 20 June 1983
(2) to test further the hypothesis that malignant mesothelioma mainly occurs after exposure to amphibole types of asbestos rather than chrysotile. ${ }^{13}$

\section{The process}

This factory began work in 1913. Initially, there were two main processes: (1) to produce a compressed rubber asbestos sheet packing material and (2) to make a material of mill board type on wet machines for use in clutch facings and moulded brake band linings. From the late 1930s dry moulded and roll extruded wire back brake linings were made. The dry process was discontinued about 1970 , but the roll extruded process is still in operation. Other developments in the 1930s were the introduction of a die cast process for industrial clutch facings and the use of some of the rubber 
asbestos sheeting for "sheeter" brake linings.

In the 1940 s automatic transmission friction materials, friction discs, and bands were introduced and produced in substantial volume. The first product was a semimetallic material made on a cylinder type wet machine. Subsequently, an asbestos containing paper was produced on a Fourdrinier paper machine.

Chrysotile, mainly from Canada, was the only mineral type of asbestos used until 1957, when some anthophyllite was added in making paper discs and bands. About $400 \mathrm{lb}$ of crocidolite was handled experimentally on a few occasions in the laboratory but only between 1964 and 1972 .

\section{Study group}

A cohort was defined in the same way as in the other two plants-namely, everyone who had been employed for a calendar month or more before 1 January 1959 and who had a social security number and name that matched with data in United States social security files. ${ }^{1}$

The definition of this cohort was complicated by the fact that the plant under study developed from an earlier asbestos textile plant some 10 miles away which manufactured woven brake linings from 1905 until 1939. In this plant brake lining bands were woven and then impregnated with resins and finished. The administrative departments and laboratories where processes were developed were located in the parent plant until 1939. When, in 1939 , the parent plant was closed some $400 \mathrm{em}$ ployees (and their personnel records) were transferred to the non-textile brake lining factory that is the subject of our study. As it was not possible in the earlier stages of our survey to identify the people who had also worked in the parent plant, they were included in our initial cohort and therefore in the preliminary report on the three factories. ${ }^{5}$ Subsequent research into work history records on microfilm found that certain numbered departments (28 to 50) were in the woven brake lining plant. Everyone recorded as having worked in these departments was excluded from the cohort that is the subject of this paper, reducing its size from the 4028 men and 931 women initially reported to 3641 men and 905 women.

Vital status was established as of 31 December 1977 in the same way as for the other two plants. Of the men, $3513(96.5 \%)$ were traced, $1267(36 \%)$ had died, and death certificates were obtained for 1228 (96.9\%). Of the 905 women, $819(90.5 \%)$ were traced, $114(13.9 \%)$ had died, and death certificates were obtained for $112(98 \cdot 2 \%)$. Causes of death were coded as in the other two plants by the same qualified nosologist using the 7th revision of the International Classification of Diseases.

The present report is concerned with men only. Table 1 shows deaths by cause and age at death.

\section{Exposure}

As with the other two factories information on exposure in the 1930s was available from surveys conducted by the Metropolitan Life Insurance Company in 1930,1935, 1936, and 1939. There was little subsequent information on environmental conditions until the 1970s. The hygienist member of our team (AJW) visited the plant in September 1980 , examined records, and, from long term staff and employees, obtained information on processes and jobs since the plant started, and on environmental conditions and dust controls. From these he made the best estimates he could of exposures by process and period. These are summarised in table

Table 1 Male deaths by age and certified cause

\begin{tabular}{|c|c|c|c|c|}
\hline \multirow[t]{2}{*}{ Cause of death (ICD code) } & \multicolumn{3}{|c|}{ Age at death $(y)$} & \multirow[t]{2}{*}{ Total } \\
\hline & $<45$ & $45-64$ & $\geqslant 65$ & \\
\hline $\begin{array}{l}\text { All causes } \\
\text { Malignant neoplasms: } \\
\text { Lung (162-64) } \\
\text { Oesophagus and stomach (150-51) } \\
\text { Colon and rectum (152-54) } \\
\text { Other abdominal (155-59) } \\
\text { Larynx (161) } \\
\text { Other (140-48; } 160 ; 165-205) \\
\text { Heart disease (400-443) } \\
\text { Respiratory tuberculosis (001-008) } \\
\text { Other respiratory (470-522; 525-527) } \\
\text { Pneumoconiosis (523-24) } \\
\text { Cerebrovascular (330-34) } \\
\text { Accidents (800-999) } \\
\text { Other known causes } \\
\text { Cause not known }\end{array}$ & $\begin{array}{r}139 \\
1 \\
0 \\
3 \\
4 \\
0 \\
11 \\
39 \\
3 \\
2 \\
0 \\
5 \\
35 \\
30 \\
6\end{array}$ & $\begin{array}{r}616 \\
47 \\
12 \\
9 \\
9 \\
3 \\
50 \\
273 \\
6 \\
27 \\
7 \\
30 \\
42 \\
87 \\
14\end{array}$ & $\begin{array}{r}511 \\
41 \\
13 \\
20 \\
12 \\
1 \\
40 \\
198 \\
2 \\
24 \\
5 \\
56 \\
15 \\
66 \\
18\end{array}$ & $\begin{array}{r}1267 \\
89 \\
25 \\
32 \\
25 \\
4 \\
101 \\
510 \\
11 \\
53 \\
12 \\
91 \\
92 \\
183 \\
39^{*}\end{array}$ \\
\hline
\end{tabular}

*Including one age unknown. 
2. Before 1970, measurements were made by impinger in million particles per cubic foot (mpcf); subsequently membrane filters were used. Conversion of particle to fibre measurements has not been attempted because of the large amount of work it entailed and the meagre confidence which we could have placed in the resulting estimates.

In the 1930s dust levels were generally around 1-5 mpcf except for certain processes-opening and preparation of fibre for the asbestos rubber sheet packing, mixing fibre for extruded brake linings, and grinding and finishing-where levels were much higher.

The employees' work histories in this plant gave the identity number of the department in which the work was done but seldom specified the job or process. Exposure estimates had therefore to be made for departments rather than processes. In some departments there was one very dusty process on which few employees worked and other less dusty processes on which many employees worked. The more dusty process had to be taken into account in estimating departmental dust levels, which may have resulted in some general overestimation of exposures for most employees in these departments and underestimation for a few.

Period of employment (table 3 ) in this plant was similar to that in the two other plants. The average net service was 8.7 years compared with 7.6 in South Carolina and 9.2 in Pennsylvania. The mean age at start of employment was a little higher in Connecticut-30.9 years compared with 25.8 and 28.9 years in the other two plants respectively. The average dust concentration to which the men were exposed was similar to that in South Carolina-1.84 mpcf compared with $1.80 \mathrm{mpcf}$-and somewhat lower than in Pennsylvania (2.32 mpcf).

\section{Statistical analyses}

Two methods of analysis were used as already described': the man-years life table method of Hill ${ }^{\circ}$ and the internal case-control log rank procedure described by Mantel and Haenszel.' For the manyears analysis age, sex, race, and year specific death rates for Connecticut were used. For all causes of

Table 2 Estimated average dust concentrations (mpcf) for main processes 1930-70

\begin{tabular}{|c|c|c|c|c|}
\hline & $1930-9$ & $1940-9$ & $1950-9$ & $1960-9$ \\
\hline \multirow{7}{*}{$\begin{array}{l}\text { Pulverising waste asbestos products } \\
\text { Sheet packings: } \\
\text { Fibre room } \\
\text { Mixing } \\
\text { Other } \\
\text { Millboard: wet machines } \\
\text { Wire mould extruded brake lining: } \\
\text { Mixing } \\
\text { Other }\end{array}$} & 6 & 4 & 2 & 1 \\
\hline & 13.4 & 10 & 8 & 6 \\
\hline & $2 \cdot 4$ & 2 & $1 \cdot 5$ & 1 \\
\hline & $2 \cdot 0$ & $1 \cdot 5$ & 1 & 0.5 \\
\hline & $3 \cdot 1$ & 2 & 2 & 0.5 \\
\hline & $8 \cdot 2$ & 3 & 2 & \\
\hline & 1 & 3 & 0.5 & 0.2 \\
\hline \multicolumn{5}{|l|}{ Paper: } \\
\hline Autotransmission etc & - & - & 0.5 & 0.2 \\
\hline Novabestos process & - & - & 0.2 & $0 \cdot 2$ \\
\hline Grooving & - & - & 0.5 & 0.2 \\
\hline Metal fabrication & - & - & 1 & 0.5 \\
\hline Brake shoes & - & - & 0.5 & 0.2 \\
\hline Core & - & - & 0.5 & $0 \cdot \overline{2}$ \\
\hline Disc brake & 2 & $1 \cdot 5$ & 1 & 0.5 \\
\hline Treat/cure & 2 & 1.5 & 1 & 0.5 \\
\hline \multicolumn{5}{|l|}{ Brake finish/hot press: } \\
\hline Drymould mix & 24 & 10 & $7 \cdot 5$ & 5 \\
\hline Grinding & $4 \cdot 3$ & 3 & 2 & 1 \\
\hline Other & 1.5 & 1.5 & 1 & 0.5 \\
\hline $\begin{array}{l}\text { Ring finish (grinding) } \\
\text { Packing }\end{array}$ & $5 \cdot 6$ & 4 & 2 & 1 \\
\hline $\begin{array}{l}\text { Packing } \\
\text { Warehouse }\end{array}$ & $\frac{1}{2}$ & $\frac{1}{2}$ & $\begin{array}{l}0.5 \\
0.2\end{array}$ & $\begin{array}{l}0.1 \\
0.1\end{array}$ \\
\hline
\end{tabular}

Table 3 Age at start, duration of employment, and dust exposure (men only)

\begin{tabular}{|c|c|c|c|c|c|}
\hline & \multicolumn{5}{|c|}{ Duration of gross service (y) } \\
\hline & $<1$ & $1-<5$ & $5-<20$ & $\geqslant 20$ & Total \\
\hline \multirow[t]{2}{*}{$\begin{array}{l}\text { No } \\
\text { Average age at start }(y) \\
\text { Gross service }(y) \\
\text { Net service }(y) \\
\text { Average dust concentration } \\
\text { (mpcf) }\end{array}$} & $\begin{array}{r}1253 \\
29.62 \\
0.38 \\
0.37\end{array}$ & $\begin{array}{r}938 \\
31.96 \\
2.53 \\
2.12\end{array}$ & $\begin{array}{r}577 \\
33.95 \\
10.58 \\
9.00\end{array}$ & $\begin{array}{l}747 \\
29.64 \\
30.59 \\
28.82\end{array}$ & $\begin{array}{r}3515 \\
30.95 \\
9.05 \\
8.04\end{array}$ \\
\hline & $2 \cdot 28$ & 2.06 & 1.56 & 1.06 & $1 \cdot 84$ \\
\hline
\end{tabular}


Table 4 Male deaths 20 years after first employment, by cause, in relation to duration of service

\begin{tabular}{|c|c|c|c|c|c|c|c|c|c|c|}
\hline \multirow[t]{3}{*}{ Cause of death* } & \multicolumn{10}{|c|}{ Duration of gross service (y) } \\
\hline & \multicolumn{2}{|l|}{$<1$} & \multicolumn{2}{|c|}{$1-<5$} & \multicolumn{2}{|c|}{$5-<20$} & \multicolumn{2}{|l|}{$\geqslant 20$} & \multicolumn{2}{|c|}{ Complete cohort } \\
\hline & 0 & $S M R$ & 0 & $S M R$ & 0 & $S M R$ & 0 & $S M R$ & 0 & $S M R$ \\
\hline All causes & 246 & $129 \cdot 9$ & 189 & $104 \cdot 0$ & 130 & $104 \cdot 8$ & 238 & $97 \cdot 2$ & 803 & $108 \cdot 5$ \\
\hline Malignant neoplasms: & 60 & 144.9 & 50 & $125 \cdot 7$ & 29 & 114.0 & 63 & $118 \cdot 3$ & 202 & 126.5 \\
\hline Respiratory & 24 & $180 \cdot 0$ & 19 & $149 \cdot 4$ & 9 & 122.6 & 21 & 133.4 & 73 & 148.7 \\
\hline Digestive & 17 & 132.9 & 16 & $128 \cdot 3$ & 5 & 60.6 & 21 & 116.9 & 59 & $114 \cdot 4$ \\
\hline Other & 19 & $120 \cdot 4$ & 25 & 164.9 & 15 & $190 \cdot 4$ & 21 & $107 \cdot 2$ & 70 & $115 \cdot 9$ \\
\hline Heart disease & 99 & $125 \cdot 3$ & 79 & $104 \cdot 9$ & 44 & $83 \cdot 7$ & 100 & 93.1 & 322 & $102 \cdot 5$ \\
\hline Respiratory tuberculosis & 0 & - & 0 & - & 0 & - & 4 & $283 \cdot 3$ & 4 & $145 \cdot 9$ \\
\hline Other respiratory: & 13 & $196 \cdot 3$ & 8 & $126 \cdot 2$ & 4 & $85 \cdot 2$ & 8 & $92 \cdot 2$ & 33 & \\
\hline Pneumoconiosis & (6) & & (3) & & (1) & & (2) & & (12) & \\
\hline Cerebrovascular & 18 & $137 \cdot 6$ & 14 & $108 \cdot 4$ & 15 & $142 \cdot 7$ & 20 & $102 \cdot 4$ & 67 & $119 \cdot 6$ \\
\hline Accidents & 11 & $121 \cdot 1$ & 5 & $69 \cdot 2$ & 5 & $101 \cdot 7$ & 7 & $68 \cdot 6$ & 28 & $89 \cdot 1$ \\
\hline Other known & 37 & $123 \cdot 5$ & 24 & $90 \cdot 4$ & 29 & $147 \cdot 1$ & 35 & $87 \cdot 9$ & 125 & $107 \cdot 7$ \\
\hline
\end{tabular}

"As in table 1, except that ICD codes 160-64 are here grouped under "respiratory" malignant neoplasms and the "other respiratory" category includes only bronchitis, pneumonia, and pneumoconiosis (ICD 490-502, 523-4).

Table 5 Male deaths 20 years after first employment, by cause, in relation to dust exposure (mpcf.y)

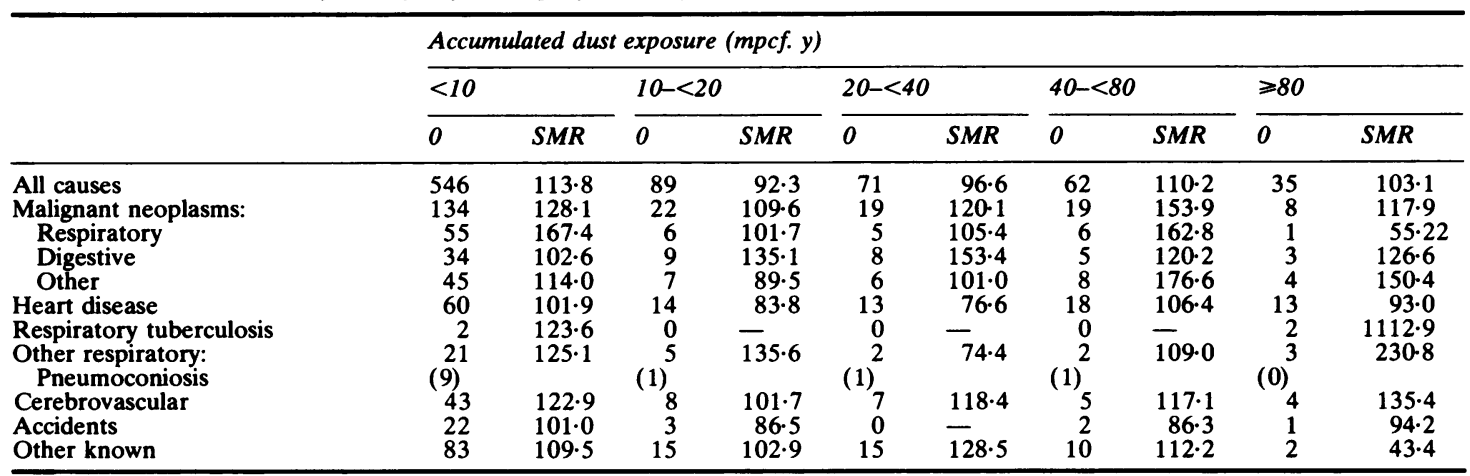

death and respiratory cancer, further analyses were made using United States rates for comparison.

\section{Results}

Table 4 summarises the mortality experience of the cohort by duration of work. The standardised mortality ratio (SMR) based on Connecticut rates was $108.5(107.9$ on United States rates). The excess (see table 4) was mainly due to people who had worked for less than one year (SMR 129.9); those who worked one or more years had an SMR of 101.2. The lowest SMR (97.2) was for those who had worked 20 or more years. SMRs were raised for the three main groups of malignant neoplasms. Again this was mainly due to high SMRs in men employed for less than one year; in none was there evidence of increasing risk with increasing duration of exposure. There was no mention of mesothelioma on any death certificate. SMRs for heart disease and cerebrovascular disease showed the same pattern.
Table 5 gives SMRs by total accumulated dust exposure. The same lack of any clear or systematic exposure-effect pattern is present. The SMR for respiratory cancer for men in the two highest dust groups combined $(125.8)$ was higher than for the two intermediate dust groups combined (103.3) but still substantially below that for the lowest exposure category (167.4). A similar pattern of relative risk was obtained from the Mantel-Haenszel analysis (see table 6) which showed an increasing risk only if the minimal exposure group is ignored.

The other respiratory group of diseases that included pneumoconiosis (ICD 523) also showed little indication of an exposure response. Six of the 12 whose deaths were coded to pneumoconiosis (ICD 523) had worked in the plant for less than a year and only three of the 12 had a total dust exposure index of $10 \mathrm{mpcf}$.y or more. Table 7 shows details from the 12 death certificates given ICD code 523. In no case was asbestosis mentioned but anthracosilicosis or silicosis were given as the cause of 
Table 6 Relative risks of respiratory cancer by dust exposure from (1) Mantel-Haenszel analysis and (2) SMRs

\begin{tabular}{|c|c|c|c|c|c|c|c|}
\hline & \multicolumn{5}{|c|}{$m p c f . y$} & \multicolumn{2}{|l|}{ Chi-square } \\
\hline & $<10$ & $10-<20$ & $20-<40$ & $40-<80$ & $\geqslant 80$ & Difference & Linearity \\
\hline $\begin{array}{l}\text { Mantel-Haensze } \\
\text { Observed } \\
\text { Expected } \\
\text { Relative risk }\end{array}$ & $\begin{array}{c}54 \\
51 \cdot 1 \\
1\end{array}$ & $\begin{array}{l}4 \\
8 \cdot 7 \\
0 \cdot 40\end{array}$ & $\begin{array}{l}5 \\
4 \cdot 6 \\
0.91\end{array}$ & $\begin{array}{l}6 \\
4 \cdot 1 \\
1 \cdot 40\end{array}$ & $\begin{array}{l}1 \\
1 \cdot 5 \\
1 \cdot 13\end{array}$ & $4 \cdot 50$ & 0.00 \\
\hline $\begin{array}{l}\text { From SMRs: } \\
\text { Relative risk }\end{array}$ & 1 & 0.59 & 0.64 & 0.98 & $0 \cdot 31$ & & \\
\hline
\end{tabular}

Table 7 Deaths attributed to pneumoconiosis (ICD 523)

\begin{tabular}{|c|c|c|c|c|c|c|c|}
\hline \multirow[t]{2}{*}{ Case No } & \multicolumn{3}{|c|}{ Employment } & \multirow{2}{*}{$\begin{array}{l}\text { Birth } \\
\text { place }\end{array}$} & \multicolumn{2}{|c|}{ Death } & \multirow[t]{2}{*}{ Certified cause } \\
\hline & $\begin{array}{l}\text { Age at } \\
\text { start }(y)\end{array}$ & Duration & $\begin{array}{l}\text { Total dust } \\
\text { (mpcf.y) }\end{array}$ & & $\begin{array}{l}\text { Age } \\
(y)\end{array}$ & Place & \\
\hline $\begin{array}{l}1 \\
2 \\
3 \\
4 \\
5 \\
6 \\
7\end{array}$ & $\begin{array}{l}36 \\
26 \\
35 \\
29 \\
38 \\
22 \\
50\end{array}$ & $\begin{array}{l}2 \text { months } \\
6 \text { months } \\
2 \text { months } \\
5 \text { months } \\
10 \text { months } \\
3 \text { months } \\
1 \text { y } 10 \mathrm{~m}\end{array}$ & $\begin{array}{l}0.1 \\
0.2 \\
0.1 \\
0.2 \\
0.7 \\
0.1 \\
2 \cdot 0\end{array}$ & $\begin{array}{l}\text { Sandy Run, Pa } \\
\text { Taylor, Pa } \\
\text { Wilkes-Barre, Pa } \\
\text { Wilmington, De } \\
\text { Pennsylvania } \\
\text { Wyoming, Pa } \\
\text { Mexico }\end{array}$ & $\begin{array}{l}64 \\
57 \\
57 \\
58 \\
68 \\
53 \\
79\end{array}$ & $\begin{array}{l}\text { Freeland, Pa } \\
\text { Taylor, Pa } \\
\text { Wilkes-Barre, Pa } \\
\text { Wilkes-Barre, Pa } \\
\text { Wilkes-Barre, Pa } \\
\text { Wyoming, Pa } \\
\text { Windber, Pa }\end{array}$ & $\begin{array}{l}\text { Anthracosilicosis } \\
\text { Silicosis and emphysema } \\
\text { Anthracosilicosis } \\
3^{\circ} \text { anthracosilicosis } \\
\text { Anthracosilicosis } \\
\text { Anthracosilicosis } \\
\text { Coal workers } \\
\text { pneumoconiosis }\end{array}$ \\
\hline $\begin{array}{r}8 \\
9 \\
10 \\
11 \\
12\end{array}$ & $\begin{array}{l}47 \\
35 \\
51 \\
40 \\
31\end{array}$ & $\begin{array}{l}3 \text { years } \\
3 \text { years } \\
20 \text { years } \\
16 \text { years } \\
30 \text { years }\end{array}$ & $\begin{array}{r}6 \cdot 8 \\
17 \cdot 4 \\
8 \cdot 3 \\
21 \cdot 8 \\
51 \cdot 4\end{array}$ & $\begin{array}{l}\text { Scranton, Pa } \\
\text { Nanticoke, Pa } \\
\text { Scranton, Pa } \\
\text { Nanticoke, Pa } \\
\text { Nanticoke, Pa }\end{array}$ & $\begin{array}{l}75 \\
58 \\
72 \\
68 \\
62\end{array}$ & $\begin{array}{l}\text { Scranton, Pa } \\
\text { Nanticoke, Pa } \\
\text { Bridgeport, Ct } \\
\text { Bridgeport, Ct } \\
\text { Bridgeport, Ct }\end{array}$ & $\begin{array}{l}\text { Anthracosilicosis } \\
\text { Silicosis } \\
\text { Pulmonary silicosis } \\
\text { Pneumoconiosis } \\
\text { Pneumoconiosis }\end{array}$ \\
\hline
\end{tabular}

death in all but two. It was further noted that all 12 had either been born or had died in the coal mining area of Pennsylvania.

\section{Discussion}

It is inherent in occupational epidemiology that cohort studies of mortality that show little convincing evidence of increased risk are difficult to interpret with precision or certainty. The doubts stem mainly from problems in correctly assessing exposure, on the one hand, and in finding a truly comparable reference population from which to calculate expected deaths, on the other. The most confusing aspect of this study is the fact that the only subcohort with SMRs clearly above expectation comprises men employed for less than one year. This finding applies to all causes of death in toto and to virtually all specific diagnostic categories and is the same whether Connecticut or United States rates are used for reference. The more detailed analysis for respiratory cancer in table $\mathbf{8}$ shows that the same pattern is shared by men in the lowest accumulated dust category regardless of duration of employment. Thus were it not for the subjects with minimal employment or dust exposure, or both, the mortality experience of this cohort would be close to expectation.
Table 8 Male deaths from respiratory cancer 20 years after first employment in relation to duration of service and dust exposure

\begin{tabular}{|c|c|c|c|c|}
\hline \multirow{3}{*}{$\begin{array}{l}\text { Duration of } \\
\text { service }(y)\end{array}$} & \multicolumn{4}{|c|}{ Dust exposure (mpcf.y) } \\
\hline & $<10$ & $10-<40$ & \multicolumn{2}{|c|}{$\geqslant 40$} \\
\hline & $O S M R$ & $O S M R$ & 0 & $S M R$ \\
\hline $\begin{array}{l}<1 \\
1-<5 \\
\geqslant 5\end{array}$ & $\begin{array}{l}24180.0 \\
17166.3 \\
14150.0\end{array}$ & $\begin{array}{lr}0 & - \\
2 & 83 \cdot 2 \\
9 & 109 \cdot 9\end{array}$ & $\begin{array}{l}\mathbf{0} \\
\mathbf{0} \\
\mathbf{7}\end{array}$ & $\overline{125 \cdot 4}$ \\
\hline
\end{tabular}

These findings suggest that some selective process may have led to the employment of men of relatively poor health or health habits (heavy smokers perhaps) into low exposure jobs on which they often remained for a fairly short time. This type of selection is common in industry, tending to offset the so called healthy worker effect. We also considered the possibility that the short term employees had worked in other hazardous industries before or after employment in the asbestos plant. This certainly appears to have been the explanation of all or nearly all the deaths from pneumoconiosis. We reviewed the company records and the death certificates of all the men with respiratory cancer with emphasis on those in the lowest exposure category ( $<10$ mpcf.y) to see what work they had done immediately before 


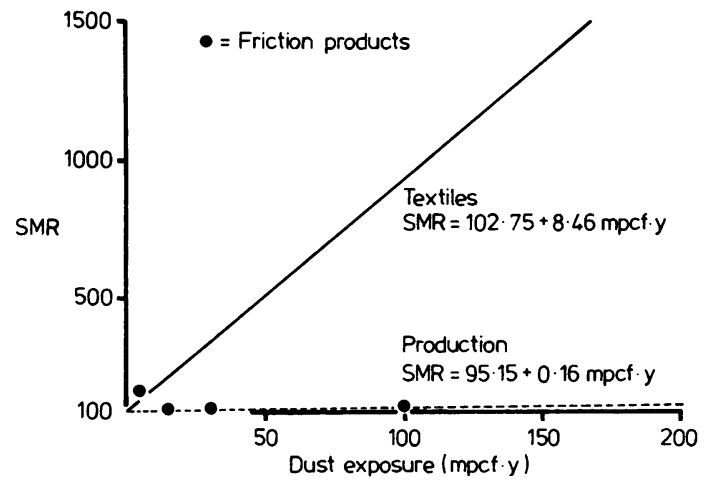

Respiratory cancer SMRs and dust exposure in chrysotile friction products manufacture compared with chrysotile textile manufacture ${ }^{*}$ and chrysotile production. *

*Lines fitted to exposure-response results using dust accumulated to age 45 are as described in previous paper. ${ }^{1}$

employment in the plant and immediately before death. Some of the recorded jobs could have entailed exposure to asbestos, but no convincing explanation of these cases was discovered.

To summarise, if we accept that the high mortality from all causes (including respiratory cancer) in men employed for less than one year was probably due to some form of selection, our results suggest that the adverse health effects of employment in this chrysotile friction products plant were small. Berry and Newhouse have recently reported the results of a much larger cohort in a British friction products plant in which they found no excess whatever of respiratory cancer. ${ }^{8}$ The exposure levels in the two factories appear to have been similar. Although compatible with the same conclusion, our findings are less certainly negative; indeed, at face value they are similar to the experience of Quebec chrysotile miners and millers. ${ }^{3}$ In the figure are plotted the exposure-response lines for respiratory cancer in chrysotile production and in a South Carolina chrysotile textile plant;' the latter were also studied with similar results by Dement $e t$ al. ${ }^{9}$ In the figure are also shown the SMRs of respiratory cancer from the present study. There can be no doubt as to which of the two lines the friction workers approximate.

A noteworthy feature of the Berry and Newhouse study $^{8}$ was that although chrysotile was virtually the only type of asbestos used, for two well defined periods (1929-33 and 1939-44) crocidolite was used for a specific contract in one particular workshop. There were 11 deaths from mesothelioma in that cohort and the evidence strongly suggested that these cases resulted from the crocidolite operation. In our plant no amphibole asbestos was used (until after 1957) and no mesothelioma was found. Similar results were observed in the two textile plants we have already described, one in which chrysotile only was used ${ }^{\prime}$ and the other which also used some amphibole fibre. ${ }^{2}$ The risk of lung cancer was the same (high) but there was a big difference in the frequency of mesothelioma. ${ }^{6}$

These major features of the mineral fibre picture, already evident but poorly substantiated in $1964,{ }^{10}$ become clearer: amphibole fibres are the main cause of mesothelioma and, with chrysotile, the risk of lung cancer varies greatly with industrial process. At the low end of the risk scale are mining and milling and the simple mixing operations required in the manufacture of friction products and perhaps asbestos cement; at the high end are textile manufacture and perhaps insulation work. The explanation of these differences, which is of great social importance, is still open. We are inclined to believe that the much more traumatic industrial processes carding, weaving, cutting, grinding, and trimming - probably increase the concentration of the fine, mainly submicroscopic fibres that experimental workers suggest are the most carcinogenic. ${ }^{11} 12$ Until these questions are understood neither environmental control measures nor the use of man-made fibre substitutes ${ }^{5}$ can be firmly based.

Many people and organisations helped in most aspects of this research. We thank especially Fred Walker for tracing, Sharon Nixon for data processing, and Roslyn MacNish for coding causes of death. A grant toward the cost of the study was made to St Mary's Hospital Medical School by the Institute of Occupational and Environmental Health of the Quebec Asbestos Mining Association. Facilities for completing the study were provided to Dr A D McDonald by the Institut de recherche en santé et en sécurité du Québec.

Requests for reprints to: Dr J C McDonald, School of Occupational Health, McGill University, 1130 Pine Avenue West, Montreal, Canada H3A 1A3.

\section{References}

' McDonald AD, Fry JS, Woolley AJ, McDonald JC. Dust exposure and mortality in an American chrysotile textile plant. Br J Ind Med 1983;40:361-7.

${ }^{2}$ McDonald AD, Fry JS, Woolley AJ, McDonald JC. Dust exposure and mortality in an American factory using chrysotile amosite and crocidolite in mainly textile manufacture. $\mathrm{Br} J$ Ind Med 1983;40:368-74.

3 McDonald JC, Liddell FDK, Gibbs GW, Eyssen GE, McDonald AD. Dust exposure and mortality in chrysotile mining, 191075. Br J Ind Med 1980;37:11-24. 
4 McDonald JC. Asbestos related disease: an epidemiological review. In: Wagner JC, ed. Biological effects of mineral fibres. Lyon: International Agency for Research into Cancer, 1980: 811-7. (Scientific publication No 30.)

${ }^{5}$ McDonald AD, Fry JS. Mesothelioma and fibre type in three American asbestos factories; preliminary report. Scand $J$ Work Environ Health 1982;8 (suppl):53-8.

- Hill ID. Computing man years at risk. Br J Prev Soc Med 1972;26:132-4.

${ }^{7}$ Mantel N, Haenszel W. Statistical aspects of the analysis of data from retrospective studies of disease. J Natl Cancer Inst 1959;22:719-48.

- Berry G, Newhouse ML. Mortality of workers manufacturing friction materials using asbestos. Br J Ind Med 1983;40:1-7.

- Dement JM, Hams RL, Symons MJ, Shy C. Estimates of dose response for respiratory cancer among chrysotile asbestos tex- tile workers. Ann Occup Hyg 1982;26:869-87.

${ }^{10}$ Geographical Pathology Committee of the International Union against Cancer. Report and recommendations of the working group on asbestos and cancer. $\mathrm{Br} J$ Ind $\mathrm{Med}$ 1965;22:165-71.

" Pott F. Some aspects on the dosimetry of the carcinogenic potency of asbestos and other fibrous dusts. Staub-Reinhaliung der Luft 1978;38:486-90.

12 Stanton MF. Some etiological considerations of fibre carcinogenesis. In: Bogovski G, Gilson JC, Timbrell V, Wagner JC, eds. Biological effects of asbestos. Lyon: International Agency for Research into Cancer, 1973: 284-94. (Scientific publication No 8.)

${ }^{13}$ McDonald JC. Aspects of the asbestos standard. In: Gee JBL, Morgan WKC, Brooks SM, eds. Occupational lung disease. New York: Raven Press, 1984:139-49. 